\title{
E-Government, Audit
}

\section{Opinion, and Performance of Local Government Administration in Indonesia}

\author{
Bambang Sutopo ${ }^{1}$, Trisninik Ratih Wulandari ${ }^{2}$, Arum Kusumaningdyah Adiati $^{3}$ and Dany \\ Adi Saputra ${ }^{4}$
}

\begin{abstract}
Local governments (LGs) have an important role in providing services to the community. Nevertheless, some local governments still show relatively low performance. Scores of egovernment implementation and audit opinions obtained by some local governments are also relatively low. This study examines whether there are relationships between e-government, the dimensions of e-government, and audit opinion and the performance of the local government administration. There are five dimensions of the e-government i.e. policy, institutions, infrastructure, applications, and planning. The sample used in this study includes 246 local governments from 2012 to 2014. Using regression analysis, the results of this study show that egovernment has a positive association with the performance of the local government administration. This is supported by the positive association of e-government's dimensions with performance. The audit opinion is also positively associated with performance as expected. These results suggest that e-government and audit opinion can be used as indicators of the performance of local government administration. ${ }^{5}$
\end{abstract}

JEL Classification: M48

Keywords: e-government, audit opinion, the performance of local government administration

\footnotetext{
${ }^{1}$ Universitas Sebelas Maret, Indonesia.

${ }^{2}$ Universitas Sebelas Maret, Indonesia.

${ }^{3}$ Universitas Sebelas Maret, Indonesia.

${ }^{4}$ Universitas Sebelas Maret, Indonesia.

${ }^{5}$ We would like to thank the participants of the International Accounting Conference in Yogyakarta 27-29 August 2017 for their helpful comments.
} 


\section{INTRODUCTION}

Local governments (LGs) have the duty to perform the task of providing high-quality services to the communities in their respective regions. In order for these tasks to be carried out, high-quality local government administration is required. To find out the results of the implementation of these tasks, the evaluation of local governmental performance is done annually through the Decree of the Minister of Home Affairs on the Determination of Rating and Performance Status of Local Government Administration. The overall performance score ranges from 0 to 4 . Local governments are expected to provide the high-quality of services to community indicated by the high-performance score. However, some local governments had relatively low-performance scores.

Local governments began to implement e-government to improve the quality of service to the community. E-government is a relatively new government activity. Each local government is assessed and ranked based upon e-government implementation quality with a score ranging from 1 to 4 . The scores obtained by local governments vary. UNDESA (2014) reports that in terms of e-service, Indonesia is still included in the middle group. A case study by Dewi (2011) finds a successful e-government implementation in a village of the Province of Yogyakarta. However, there are obstacles in resources, location, and technical knowledge faced by the village. A description of LG's performance and the quality of e-government raises the question of whether there is an association between e-government and performance.

In carrying out the service function to the community, the local government prepares the revenue and expenditure budget and reports on the realization of the budget that is part of the financial statements. To assess the quality of these financial statements, an audit of financial statements is performed by the Audit Board (BPK; List of terms and abbreviations is presented in Appendix). Implementation of the audit uses the guidelines of state audit standard (BPK, 2017). A summary of the semester audit result (IHPS) is published at the BPK website as a form of accountability to the public. In the IHPS, among others, is reported a summary of audit opinions on the financial statements. An audit opinion reflects the quality of financial statements. Some local governments succeed in getting unqualified opinions, but in relatively small numbers. There are still many local governments that get opinions other than unqualified opinion. For example, Mir and Sutiyono (2013) report that there is an increase in audit reports that get a qualified opinion. The description of the audit opinion raises the second question, i.e. whether there is an association between audit opinion and performance. The results of a qualitative study by Hudaya, Smark, Watts, and Silaen (2015) relating to reports of local government accountability to the public indicate that reports accessible to the public are only brief reports, not as complete as reports for the central government, and those reports are often inaccessible to communities in a timely manner. Lin, Jiang, Tang, and He (2014) in a study on the use of quality financial reports in the private sector suggest that the financial statements' quality could reduce information asymmetry.

Previous studies have been conducted in the private sector on performance using various measures of performance, such as liquidity or bid-ask spread (Lin et al., 2014), accounting such ROA and Tobin's Q (Buallay, Hamdan, \& Zureigat, 2017; Rashid, Zoysa, Lodh, \& Rudkin, 2010; Zeituna \& Tian, 2007), and short-term aftermarket performance (underpricing) and longrun performance (Thorsell \& Isaksson, 2014). Studies on performance in the public sector also use different performance measures such as performance expectations (James, 2011) and expenditure per capita, service performance, and value for money (Andrews \& Boyne, 2012). In Indonesia, previous studies on the performance of local governments were conducted among 
others by Jurnali and Siti-Nabiha (2015) using government agency's performance accountability report (LAKIP) as a performance measure and by Saputra (2016) using the performance of local government administration. However, the implementation of LAKIP has weaknesses (Jurnali \& Nabiha (2015), while Saputra (2016) does not examine audit opinions as one of the key factors that may affect performance and he finds that among the dimensions of e-government, only the dimension of infrastructure is related to performance.The results may be due to multicollinearity problems. This study extends the previous study of Saputra (2016) by improving the test model, extending the observation period, and contributing the audit opinion as an explanatory variable. More specifically, this study investigates whether e-government and audit opinion are associated with local government administration performance in Indonesia. The empirical results of this research are expected to be useful in providing input in policy formulation and useful to all stakeholders including the community in assessing the performance of local government.

\section{LITERATURE REVIEW AND HYPOTHESES Performance of Local Government Administration}

The performance of local/regional governments is regulated by Law No. 23 of 2014 (Law 23/2014) on Regional Government. In the Law 23/2014 it is stated that the regional head must submit a report on the administration of regional government including a report on the performance of local government institutions. The report on the administration of the regional government contains the performance of the administration of regional government and the implementation of co-administration. The central government prepares indexes and performance ratings for the administration of the regional government each year for evaluation materials. The President gives awards to local governments that achieve the highest performance ratings nationally in the administration of regional government.

Law 23/2014 is followed up by Government Regulation No. 3 of 2007 (PP 3/2007) on Report of Local Government Administration to Government, Explanation Report of Accountability (LKPJ) of Regional Head to Regional Representative Council, and Information Report on Administration of Local Government to the Community. PP 3/2007 explains that the Report of Local Government Administration to the Government, hereinafter referred to as LPPD, is a report on the administration of local government for 1 (one) budget year based on the Regional Development Work Plan (RKPD) submitted by the head of regional government to the Government.

Law 23/2014 and PP3/2007 are then followed up by Government Regulation No. 6 of 2008 (PP 6/2008) on Guidelines for Evaluation of Local Government Administration. PP 6/2008 defines the performance of local government administration as the achievement of the implementation of local government affairs as measured by input, process, outputs, outcomes, benefits, and/or impacts. Furthermore, PP6/2008 provides an explanation on the processes of performance evaluation, the evaluation teams, the information sources, and the objectives related to the performance of local government administration.

The processes include the evaluation of regional government administration (hereinafter abbreviated as EPPD) and performance evaluation of local government administration (EKPPD). EPPD is a process of the systematical collection and analysis of data to the performance of local government administration, the ability of regional autonomy implementation, and completeness of aspects of governance in the newly formed area, whereas EKPPD is a process of collecting and analyzing data systematically to the performance of local government administration by using performance measurement system. The performance measurement system is a system used 
to measure, assess, and systematically and continuously compare the performance of local government administration. The EKPPD is conducted to assess the performance of local government administration in an effort to improve performance based on good governance principles, and it covers the measurement and ranking of the performance of regency/city government in the provinces.

The team consists of the EPPD national team which is a team that assists the president in carrying out the evaluation of local government administration nationally, EPPD regional team which is a team that helps the head of province as the representative of the government in conducting the evaluation of regency/city government in the provincial area, and the assessment team which is a team that helps governors, regents, or mayors in conducting an evaluation of the level of local policymakers and evaluation of the level of local policy implementers. The main source of information used to conduct EKPPD is the LPPD. In addition to the main source of information, complementary sources of information can be used such as accountability report of regional revenue and expenditure budget (APBD) implementation, regional financial information, performance reports of local government agencies, reports on the results of fostering, researching, developing, monitoring, evaluating and supervising the implementation of regional government affairs, report on the results of community satisfaction survey on local government services, and reports and/or other information that is accurate and clearly indicate the person(s) responsible.

The objectives of EKPPD cover the level of local policymakers and the level of local policy implementers. EKPPD at the level of local policymakers includes several aspects of assessment such as: public orderliness and tranquility, harmony and effectiveness of relations between local government and central government and inter-regional government in the context of the development of regional autonomy, alignment between local government policy with central government policy, alignment between local government and Regional Representatives Council (DPRD), effectiveness of decision making process by DPRD and follow-up of decision implementation, effectiveness of decision making process by head of region along with follow up execution of decision, obedience of implementation of local government administration on regulation, and other aspects of assessment. EKPPD at the level of local policy implementers covers several aspects of the assessment such as technical policy for the administration of government affairs, obedience to laws and regulations, level of achievement of minimum service standards, regional institutional arrangements, the management of regional personnel, regional development planning, regional financial management, management of regional property, and provision of facilitation of community participation.

\section{E-Government and Performance}

Moon (2002) uses the broad definition of e-government as the use of information and communication technology to facilitate the daily administration of government and the narrow definition as the application of information technology in producing and delivering government services. More specifically, the definition of e-government have the following characteristics: information and communication technologies that are most innovative, the applications of a webbased internet, citizens and business can access to government information and services more conveniently, improving service quality, and a greater opportunity for the community to participate in the institution processes in democratic ways (Fang, 2002).

The quality assessment of e-government in Indonesia is coordinated by Ministry of Communication and Informatics (Kemkominfo), and the results of the assessment are announced in the Indonesian e-government ranking (PeGI). The e_Gov. has 3 (three) objectives: (1) 
provides a reference for the development and utilization of information and communication technology (ICT) in the government environment, (2) provides incentives for improved ICT in the government environment through a full, balanced, and objective evaluation, and (3) looks at the map of ICT utilization conditions within the national government environment.The implementation strategy of e-Gov is as follows. First, the ranking participant is grouped according to the type of institution, namely the provincial government, regency government, city government, ministry, and non-ministerial institution. Second, the assessment uses simple elaborated criteria so easily understood by all parties. Third, methods and results of the assessment are published. Finally, evaluation is done periodically so that progress (trend) can be measured.

Assessment is based on 5 (five) dimensions: (1) policy, (2) institution, (3) infrastructure, (4) application, and (5) planning. Each dimension has the same weight in judgment because everything is important, interrelated and mutually supportive. The policy is important because it serves as the main foundation for the development and implementation of e-government. The evaluation of the policy dimension is made to the policy contained in the official documents that have legal force. The document contains, among other things, the determination of direction/purpose, work program, or arrangement for the e-government development and implementation within the participating agencies. The documents' forms may be decisions, regulations, guidelines or other forms of official documents. Adequate allocation of financing for decent ICT development and implementation includes one aspect that is evaluated in the policy dimension.

Institutional dimension is also important because it is closely related to the existence of an authorized organization and is responsible for the development and utilization of ICT. Infrastructure is also an important dimension because it is related to facilities and infrastructure that support the development and utilization of ICT, such as data centers, communications network, hardware and software, web-based service delivery channels, and supporting facilities.

The Indonesian e-Government rating methodology includes an explanation of the process to participants, filling out the questionnaire by the participants, examination of questionnaires by assessors, clarification by the assessor, and assessment and rating per participant by the assessor. The ratings provided include the rating per dimension of each participant and on the average of all participants. From the results of compilations at the national level subsequently, normalization is then carried out. The determination of the final result of the rating will be determined through the assessment of the assessor. The predetermined ranking results will be published through various media, websites, and seminars so that the results can be known by the general public. The rating of the participants for each dimension and overall is as follows: (1) $3.60 \geq$ excellent $\leq 4.00$, (2) $2.60 \geq$ good $<3.60$, (3) $1.60 \geq$ fair $<2.60$, (4) $1.00 \geq$ poor $<1.60$.

In this study, performance is the performance of local government administration that is defined as the achievement of local government affairs measured from the input, process, output, result, benefit, and/or impact (PP 6/2008). The performance score set by the Ministry of Home Affairs is used as the performance measure. E-Government (e-Gov) is the e-government rating which is expected to more motivating all government agencies in improving the utilization of ICT in serving the community, business people, and government agencies.

Previous studies have demonstrated the relationship between e-government and performance (S. Bhatnagar, 2003; S. C. Bhatnagar \& Singh, 2010; Davies, 2015; UNDESA, 2014). Computer-based services are a preference due to travel to fewer services, waiting times to receive shorter services, and reduced corruption (S. C. Bhatnagar \& Singh, 2010). Another study 
states that communications and information technology (ICT) serves as tools for data processing which faster and more efficient within public administration, specifically within the scope of public service delivery, public services that efficiently generate cost savings, or developing new types of services for the same cost (Davies, 2015). In addition, e-government increases transparency, reduces corruption, increases effective service delivery, and empowers rural communities (social impacts). E-government also reduces cost in service delivery, controls government's expenditures, increases tax revenue (S. Bhatnagar, 2003). Rokhman (2011) conducted a survey study in Indonesia on the factors affecting the intensity of e-government utilization and found that among factors affecting the intensity of e-government utilization are relative advantage and compatibility.

According to Scholl (2002), although stakeholder theory is typically used in the private sector firms, stakeholder theory can also be applied to public sector organizations. More specifically, stakeholder theory can be used in explaining e-government application by the government. This is due to the growing nature that requires a network of public sector organizations. According to stakeholder theory applied in the private sector, companies will be more successful if the company is able to maintain stakeholder satisfaction than if the company is only able to maximize profit for shareholders. The e-government characteristics as identified in the definition of e-government by Fang (2002) allow public sector organizations, such as local governments, to provide better satisfaction to stakeholders. Thus, it is expected that egovernment has an association with performance. The hypothesis is formulated as follows.

H1. E-Government is positively associated with Performance of Local Government Administration

\section{Dimensions of E-Government and Performance}

Assessment in e-government is based on 5 (five) dimensions, namely the dimensions of (1) Policy, (2) Institutional, (3) Infrastructure, (4) Application, and (5) Planning. Challenges and obstacles in the implementation and adoption of e-government include various types (Rana, Dwivedi, \& Williams, 2013). Therefore, each e-government dimension needs to be tested separately.

\section{Policy Dimensions of E-Government and Performance}

The policy dimension is the main foundation for the development and implementation of e-government. Since policy is the main basis for e-government development and implementation, the policy dimension is expected to have a positive association with performance. In addition, performance measures are also assessed on the policy aspect (PP 6/2008). This leads to the following hypothesis.

H1a. E-Government policy dimension is positively associated with the performance of local government administration

\section{Institutional Dimensions of E-Government and Performance}

The institutional dimension is closely related to the existence of an authorized organization and is responsible for the development and utilization of ICT. Because the existence of an authoritative and responsible organization for the development and utilization of ICT is closely related to the institutional dimension, the institutional dimension is expected to have a positive association with performance. In addition, performance measures also contain institutional elements (PP 6/2008). The hypothesis of the association between institutional dimension and performance is formulated as follows. 
H1b. E-Government institution dimension is positively associated with the performance of local government administration.

\section{Infrastructure Dimension of E-Government and Performance}

The infrastructure dimension is related to facilities and infrastructure that support the development and utilization of ICT. Poor management and infrastructure and lack of IT infrastructure are barriers to the successful implementation of e-government (Rana et al., 2013). Due to the facilities and infrastructure that support the development and utilization of ICT, the infrastructure dimension is expected to have a positive association with performance. In addition, the performance assessment of local government administration contains elements of facilities and infrastructure (PP 6/2008). The infrastructure-performance association hypothesis is formulated as follows.

H1c. E-Government infrastructure dimension is positively associated with the performance of local government administration.

Application Dimensions of E-Government and Performance

The dimensions of the application are related to the availability and utilization rate of application software that supports the e-government service directly (front office) or back office. Technological barriers and the digital divide are important elements to be considered in implementing e-government (Rana et al., 2013). In addition, the availability and extent of utilization of application software supporting e-government services, and performance appraisal of local government administration has application aspects (PP 6/2008). The hypothesis of the application dimension and performance relationship is as follows.

H1d. E-Government application dimension is positively associated with the performance of local government administration.

\section{Planning Dimension of e-Government and Performance}

The planning dimension is related to ICT planning or management that is done in an integrated and sustainable way. Assessment of the performance of local government administration contains elements of planning (PP 6/2008). Therefore, it is suspected that the planning dimension of e-government has a positive association with the performance of local government administration. This leads to the following hypothesis.

H1e. E-Government planning dimension is positively associated with the performance of local government administration.

\section{Audit Opinion and Performance}

An audit opinion on the local government financial statements is provided by the Audit Board (BPK). In carrying out the examination tasks, BPK has established the first audit standard in 1995 called the Government Audit Standards (SAP). Along with the amendment of the Constitution, the laws, and the regulations in the field of examination, in 2007 BPK prepared a standard of the audit with the name of State Audit Standards (SPKN). As early as 2017 BPK successfully completed refinement of SPKN 2007 which subsequently stipulated to BPK Regulation No. 1 of 2017. Since the enactment of this BPK Regulation, SPKN binds BPK as well as other parties conducting audits and that have state financial management responsibility.

Steccolini (2004) questioned whether the annual report could be used as a means of accountability for local government, and found that the annual reports of local governments did not play a significant role as a medium of communication with external users. In addition, other means of accountability for performance to stakeholders are not used by most local governments. However, (Ferraz \& Finan, 2011) suggest the usefulness of an audit report, i.e. it can be used as a 
source of information to review the impact of electoral accountability on incumbent politicians' corruption practices.

According to institutional theory, the need for an organization to show that the organization has met the expectations of the institutional environment will have an impact on the organization in choosing a control and coordination mechanism (Gupta, Dirsmith, \& Fogarty, 1994). Institutional theory is also used by Carpenter and Feroz (2001) to explain how the institutional environment influences the decision of the four states in the United States in making decisions about the selection of financial reporting mechanisms, especially in the use of generally accepted accounting principles. The local government in Indonesia has a need to demonstrate that it has implemented its programs as well as possible. Implementation of these programs is reflected in the financial statements, especially in the budget realization report that must be audited by BPK. The financial statements containing comparisons between budget and budget realization, internal control, and external audit of financial statements are important for local governments (Chan, 2003). In conducting the audit, BPK gives an opinion on local government financial statements. Auditor opinion is given on the basis of the audit result of the financial statements and shows the quality of the financial statements based on the effectiveness of internal control, the adequate disclosure of financial statement, and the compliance with Indonesian government accounting standard (IGAS), and the compliance to government regulation (BPK, 2017). Local government performance can be evaluated not only on the quality of financial reporting but it can also be evaluated broadly from the performance of local government administrations conducted by the central government through the Minister of Home Affairs. Therefore, local government with a better audit opinion is expected to also have a higher performance of local government administration. The hypothesis is formulated as follows.

H2. The audit opinion is positively associated with the performance of local government administration.

\section{RESEARCH METHODS \\ Regression Models}

Regression models to test the hypotheses are as follows.

$$
\begin{aligned}
& \text { Performance }=\alpha+\beta_{1} \mathrm{e} \_ \text {Gov }+\beta_{2} \text { Opinion }+\beta_{3} \text { D_Prov }+\beta_{4} \mathrm{D} \_ \text {City }+\beta_{5} \mathrm{D} \_ \text {Regency }+ \\
& \beta_{6} \mathrm{D} \text { Year2012 }+\beta_{7} \mathrm{D} \text { Year2013 }+\beta_{8} \mathrm{D} \text { Year2014 }+\varepsilon \\
& \text { Performance }=\alpha+\bar{\beta}_{1} \text { Policy }+\beta_{2} \text { Opinion }+\beta_{3} D \_ \text {Prov }+\bar{\beta}_{4} D \_ \text {City }+\beta_{5} D \_ \text {Regency }+ \\
& \beta_{6} D_{-} \text {Year2012 }+\beta_{7} D_{-} \text {Year2013 }+\beta_{8} D_{-} \text {Year2014 }+\varepsilon \\
& \text { Performance }=\alpha+\beta_{1} \text { Institutions }+\beta_{2} \text { Opinion }+\beta_{3} \mathrm{D} \_ \text {Prov }+\beta_{4} \mathrm{D} \_ \text {City }+\beta_{5} \mathrm{D} \_ \text {Regency }+ \\
& \beta_{6} \mathrm{D} \_ \text {Year2012 }+\beta_{7} \mathrm{D} \_ \text {Year2013 }+\bar{\beta}_{8} \mathrm{D} \_ \text {Year2014 }+\varepsilon \\
& \text { Performance }=\alpha+\beta_{1} \text { Infrastructure }+\beta_{2} \text { Opinion }+\beta_{3} \mathrm{D} \_ \text {Prov }+\beta_{4} \mathrm{D} \_ \text {City }+\beta_{5} \mathrm{D} \_ \text {Regency } \\
& +\beta_{6} \text { D_Year2012 }+\beta_{7} \text { D_Year2013 }+\bar{\beta}_{8} \text { D_Year2014 }+\varepsilon \\
& \text { Performance }=\alpha+\beta_{1} \text { Aplications }+\beta_{2} \text { Opinion }+\beta_{3} \mathrm{D} \_ \text {Prov }+\beta_{4} \mathrm{D} \_ \text {City }+\beta_{5} \mathrm{D} \_ \text {Regency }+ \\
& \beta_{6} D_{-} \text {Year2012 }+\beta_{7} D_{-} \text {Year2013 }+\bar{\beta}_{8} D_{-} \text {Year2014 }+\varepsilon \\
& \text { Performance }=\alpha+\beta_{1} \text { Planning }+\beta_{2} \text { Opinion }+\beta_{3} \mathrm{D} \_ \text {Prov }+\beta_{4} \mathrm{D} \_ \text {City }+\beta_{5} \mathrm{D} \_ \text {Regency }+ \\
& \beta_{6} \text { D_Year2012 }+\beta_{7} \text { D_Year2013 }+\beta_{8} \text { D_Year2014 }+\varepsilon
\end{aligned}
$$

where:

Performance is the performance score of local government administration. E_Gov (eGovernment) is the score set in the Indonesian e-government rating. Policies, Institutions, Infrastructure, Applications, Planning are dimensions of e_Gov. Opinion is the auditor opinion for the local government financial statements. D_Province is a dummy variable with the value of 
1 if the local government is a provincial government or with the value of 0 if the local government is a regency government or a city. D_City is a dummy variable or with the value of 1 if the local government is a city government, and 0 if the local government is a regency government or a province. D_Regency is a dummy variable with the value of 1 if the local government is a regency government or with the value of 0 if the local government is a city government or a province. D_Year2012 is a dummy variable, with the value of 1 if the year of observation is 2012 or with the value of 0 if the year of observation is other than 2012 . D_Year2013 is a dummy variable, with the value of 1 if the year of observation is 2013 or with the value of 0 if the year of observation is other than 2013. D_Year2014 is a dummy variable, with the value of 1 if the year of observation is 2014 or with the value of 0 if the year of observation is other than 2014.

\section{Operationalization of Variables \\ Dependent variable}

The dependent variable in this study is the performance of local government administration (abbreviated to Performance) which is defined as the achievement of the implementation of regional government affairs measured from inputs, processes, outputs, outcomes, benefits and/or impact (PP 6/2008). The measure of performance is the government performance score, ranging from 0 to 4, set by the Minister of Home Affairs.

\section{Independent variables}

The independent variables in this research include e-government and the dimensions of egovernment, and audit opinion. The dimensions of e-government consist of (1) Policy, (2) Institution, (3) Infrastructure, (4) Application, and (5) Planning. Measures of the e-government and the dimensions of e-government use the e-government scores ranging from 1 to 4 . The scores are grouped into 4 (four) ratings as follows: (1) $3.60 \geq$ excellent $\leq 4.00$, (2) $2.60 \geq$ good $<3.60$, (3) $1.60 \geq$ fair $<2.60$, (4) $1.00 \geq$ poor $<1.60$.

Auditor opinion is opinion given by the auditor of the Audit Board (BPK) carrying out the audits of local government financial statements. The types of opinion (and the values belonging to each type in parentheses) include an unqualified opinion (5), an unqualified opinion with an explanatory paragraph (4), a qualified opinion (3), an adverse opinion (2), and a disclaimer of opinion (1).

\section{Data Collection Method}

This research uses secondary data both for dependent and independent variables. Performance data, the dependent variable, were collected from the decrees of the Minister of Home Affairs (Kepmendagri) on the determination of ranking and status of the local government administration performance nationally, covering Kepmendagri Number 120-251 Year 2014 for performance data of 2012 and Kepmendagri Number 120-4761 Year 2014 for performance data year 2013, and Kepmendagri No. 800-35 Year 2016 for performance data year 2014). The independent variables include e-government (e-Gov) and audit opinion (Opinion). E-Gov data are collected from the results of the Indonesian e-Government ranking (PeGI) which are available at the website of the Directorate of e-Government, Directorate General of Informatics Applications, Ministry of Communications and Informatics (http://pegi.layanan.go.id/tabel-hasilpegi-4/). Opinion data are derived from the summary of semester audit result (IHPS) which can be accessed from the website of the Audit Board, BPK (http://www.bpk.go.id/ihps).

\section{Population and Sample}

The sample selection is done by considering the availability of performance, e-government, and audit opinion data. The sample frame used in this research is Kepmendagri concerning the 
determination of ranking and status of the local government administration performance as above mentioned in the section of data collection method. This study uses the Kepmendagri as sample frame containing the population or the entire performance of local government administration. The sample is selected from the sample frame, and the sample selection procedure is presented in Table 1 resulting final sample of 246 observations.

Table 1

Sampling Procedures

\begin{tabular}{|c|c|c|c|c|}
\hline \multirow{2}{*}{ Sample } & \multicolumn{4}{|c|}{ Observations } \\
\hline & 2012 & 2013 & 2014 & 2012-2014 \\
\hline \multicolumn{5}{|l|}{ Initial Sample } \\
\hline Province & 33 & 33 & 33 & 99 \\
\hline City & 92 & 91 & 93 & 276 \\
\hline Regency & 369 & 379 & 395 & 1143 \\
\hline Total & 494 & 503 & 521 & 1518 \\
\hline \multicolumn{5}{|c|}{ EGov Data that is Not Available } \\
\hline Province & 9 & 12 & 11 & 32 \\
\hline City & 81 & 75 & 76 & 232 \\
\hline Regency & 334 & 322 & 352 & 1008 \\
\hline Total & 424 & 409 & 439 & 1272 \\
\hline \multicolumn{5}{|l|}{$\underline{\text { Final Sample }}$} \\
\hline Province & 24 & 21 & 22 & 67 \\
\hline City & 11 & 16 & 17 & 44 \\
\hline Regency & 35 & 57 & 43 & 135 \\
\hline Total & 70 & 94 & 82 & 246 \\
\hline
\end{tabular}

\section{RESULTS AND DISCUSSION Descriptive Statistics}

Table 2 presents the descriptive statistics. Mean value of performance for the total sample (20122014 ) is 2.5578. Performance of provincial local government is lower compared to the performance of city or regency local governments. The mean of e-government (e Gov) for the total sample is 1.91 and the institution dimension of e Gov is 2.10 which is the highest value. Mean value of e_Gov for province local government is higher than that for city or regency local government. Mean value of the opinion is 3.71 for the total sample and 3.96, 3.86, 3.53 and for the province, city, and regency type or local government respectively. Thus, the mean value of opinion for the province is higher than that of the other two types of local government. 
Table 2

Descriptive Statistics

\begin{tabular}{|c|c|c|c|c|}
\hline Variables & Minimum & Maximum & Mean & Std. Deviation \\
\hline \multicolumn{5}{|c|}{ Total Sample $(\mathrm{N}=246)$} \\
\hline Performance & 0.6618 & 3.3879 & 2.5578 & 0.4509 \\
\hline e_Gov & 1.03 & 3.49 & 1.91 & 0.56 \\
\hline Policy & 1.00 & 3.46 & 1.82 & 0.62 \\
\hline Institutions & 1.07 & 3.53 & 2.10 & 0.56 \\
\hline Infrastructure & 1.00 & 3.62 & 1.85 & 0.61 \\
\hline Applications & 1.00 & 3.53 & 1.99 & 0.53 \\
\hline Planning & 1.00 & 3.47 & 1.79 & 0.64 \\
\hline Opinion & 1.00 & 5.00 & 3.71 & 1.04 \\
\hline \multicolumn{5}{|l|}{ Province ( $N=67$ ) } \\
\hline Performance & 1.5958 & 3.0576 & 2.4313 & 0.3175 \\
\hline e_Gov & 1.23 & 3.39 & 2.32 & 0.53 \\
\hline Policy & 1.00 & 3.46 & 2.24 & 0.61 \\
\hline Institutions & 1.47 & 3.53 & 2.50 & 0.50 \\
\hline Infrastructure & 1.00 & 3.38 & 2.28 & 0.60 \\
\hline Applications & 1.60 & 3.43 & 2.39 & 0.47 \\
\hline Planning & 1.00 & 3.47 & 2.20 & 0.64 \\
\hline Opinion & 1.00 & 5.00 & 3.96 & 0.99 \\
\hline \multicolumn{5}{|l|}{ City $(N=44)$} \\
\hline Performance & 1.4748 & 3.2898 & 2.6229 & 0.4355 \\
\hline e_Gov & 1.14 & 3.49 & 1.90 & 0.58 \\
\hline Policy & 1.00 & 3.29 & 1.82 & 0.63 \\
\hline Institutions & 1.27 & 3.53 & 2.08 & 0.58 \\
\hline Infrastructure & 1.04 & 3.62 & 1.88 & 0.62 \\
\hline Applications & 1.10 & 3.53 & 1.95 & 0.55 \\
\hline Planning & 1.00 & 3.47 & 1.73 & 0.68 \\
\hline Opinion & 1.00 & 5.00 & 3.86 & 1.03 \\
\hline \multicolumn{5}{|l|}{ Regency (N=135) } \\
\hline Performance & 0.6618 & 3.3879 & 2.5995 & 0.5001 \\
\hline e_Gov & 1.03 & 3.09 & 1.72 & 0.45 \\
\hline Policy & 1.00 & 3.17 & 1.61 & 0.52 \\
\hline Institutions & 1.07 & 3.53 & 1.92 & 0.47 \\
\hline Infrastructure & 1.00 & 3.14 & 1.63 & 0.49 \\
\hline Applications & 1.00 & 2.87 & 1.80 & 0.43 \\
\hline Planning & 1.00 & 3.07 & 1.61 & 0.52 \\
\hline Opinion & 1 & 5 & 3.53 & 1.04 \\
\hline
\end{tabular}




\section{Correlation}

E Gov and the dimensions of e Gov have a positive correlation with performance (Table 3 ). These results are consistent with the hypotheses. However, the dimensions of e_Gov are highly correlated with each other (Table 3). Therefore, each dimension will be analyzed separately in the regression models.

Table 3

Pearson Correlation

$(\mathrm{N}=\mathbf{2 4 6})$

\begin{tabular}{|c|c|c|c|c|c|c|c|c|}
\hline Variables & Performance & Policy & Institutions & Infrastructure & Applications & Planning & e_Gov & Opinion \\
\hline Performance & 1 & & & & & & & \\
\hline Policy & $.155^{*}$ & 1 & & & & & & \\
\hline Institutions & $.193 * *$ & $.874 * *$ & 1 & & & & & \\
\hline Infrastructure & $.219^{* *}$ & $.837 * *$ & $.861 * *$ & 1 & & & & \\
\hline Applications & $.229 * *$ & $.831 * *$ & $.832 * *$ & $.882 * *$ & 1 & & & \\
\hline Planning & $.191 * *$ & $.873 * *$ & $.844 * *$ & $.850 * *$ & $.809 * *$ & 1 & & \\
\hline e_Gov & $.211 * *$ & $.935 * *$ & $.931 * *$ & $.938 * *$ & $.920 * *$ & $.931 * *$ & 1 & \\
\hline Opinion & $.248 * *$ & $.167 * *$ & $.173 * *$ & $.170^{* *}$ & $.170 * *$ & $.160^{*}$ & $.173 * *$ & 1 \\
\hline
\end{tabular}

\section{Regression Results}

The regression results to test the hypothesis of the association of e-Gov with Performance (H1) is presented in Table 4. The results show that e_Gov coefficient is positive and significant (sig. $<0.01$ ). These results support the hypothesis 1 that $\mathrm{e}_{-}$Gov has a positive association with performance of local government administration. This is in line with the research (Bhatnagar 2003; Bhatnagar and Singh 2010). These results suggest that e-Gov recently developed by local governments in Indonesia is useful in evaluating the performance of local government.

The regression results in Table 4 also show that the opinion coefficient is positive and significant (sig. $<0.01$ ). This result supports hypothesis 2 that auditor opinion is positively associated with performance. A bad audit opinion is a risk to an entity (Rosman, Shafie, Sanusi, Johari, \& Omar, 2016). The results of this study indicate that poor audit results tend to show poor performance of the local government. Local government financial information for the community tends to be late or incomplete (Hudaya et al., 2015). Besides, transparency makes it easier for outsiders to analyze an organization's actions and performance (Maclean, 2014). The financial statements are required to be audited, and the auditor opinion can be used an indicator of the performance of local government administration. 
Table 4

Regression Results (H1 and H2)

Dependent Variable: Performance

\begin{tabular}{lccccc}
\hline \multicolumn{1}{c}{ Variables } & H & Pred. Sign & Coef. & t & Sig. \\
\hline (Constant) & & & 1.841 & 13.694 & 0.000 \\
e_Gov & $\mathrm{H} 1$ & + & 0.262 & 4.892 & 0.000 \\
Opinion & $\mathrm{H} 2$ & + & 0.094 & 3.434 & 0.001 \\
D_Prov & & $?$ & -0.355 & -5.071 & 0.000 \\
D_City & & $?$ & -0.057 & -0.796 & 0.427 \\
DYear2012 & $?$ & -0.112 & -1.717 & 0.087 \\
DYear2014 & & 246 & 0.016 & 0.246 & 0.806 \\
\hline N & & & & \\
F & & & & & \\
Sig. & & 0.398 & & & \\
Adjusted R Square & & 0.187 & & & \\
\hline
\end{tabular}

All the dimensions of e_Gov have positive coefficients and significant at 0.01 level (Table 5) suggesting that (1) Policy, (2) Institution, (3) Infrastructure, (4) Application, and (5) Planning dimensions of e-Gov are positively associated with the performance of local government administration. These results are consistent with the results of hypothesis 1.

Table 5

Regression Results (H1a, H1b, H1c, H1d, H1e, and H2)

Dependent Variable: Performance

\begin{tabular}{|c|c|c|c|c|c|c|c|c|c|c|c|c|}
\hline Variables & $\mathbf{H}$ & Pred. Sign & Coef. & & Coef. & & Coef. & & Coef. & & Coef. & \\
\hline (Constant) & & & 2.01 & $* *$ & 1.84 & $* *$ & 1.90 & $* *$ & 1.74 & $* *$ & 1.98 & $* *$ \\
\hline Policy & H1a & + & 0.17 & $* *$ & & & & & & & & \\
\hline Institutions & $\mathrm{H} 1 \mathrm{~b}$ & + & & & 0.24 & $* *$ & & & & & & \\
\hline Infrastructure & $\mathrm{H} 1 \mathrm{c}$ & + & & & & & 0.24 & $* *$ & & & & \\
\hline Applications & H1d & + & & & & & & & 0.31 & $* *$ & & \\
\hline Planning & H1e & + & & & & & & & & & 0.19 & $* *$ \\
\hline Opinion & $\mathrm{H} 2$ & + & 0.10 & $* *$ & 0.09 & $* *$ & 0.09 & $* *$ & 0.09 & $* *$ & 0.10 & $* *$ \\
\hline D_Prov & & $?$ & -0.30 & $* *$ & -0.33 & $* *$ & -0.36 & $* *$ & -0.38 & $* *$ & -0.31 & $* *$ \\
\hline D_City & & $?$ & -0.05 & & -0.05 & & -0.07 & & -0.06 & & -0.03 & \\
\hline DYear2012 & & $?$ & -0.14 & * & -0.12 & $*$ & -0.12 & & -0.10 & & -0.12 & \\
\hline DYear2014 & & $?$ & $* *$ & & 0.02 & & 0.03 & & 0.03 & & -0.01 & \\
\hline $\mathrm{N}$ & & & 246 & & 246 & & 246 & & 246 & & 246 & \\
\hline $\mathrm{F}$ & & & 8.24 & $* *$ & 9.61 & $* *$ & 11.42 & $* *$ & 8.24 & $* *$ & 8.99 & $* *$ \\
\hline Adj. R Square & & & 0.15 & & 0.17 & & 0.20 & & 0.15 & & 0.16 & \\
\hline
\end{tabular}

*. Significant at the 0.05 level; **. Significant at the 0.01 level 
Results of the regressions also show that the coefficient of D Prov is negative and significant at $\mathrm{p}<0.01$ indicating that province local governments tend to have lower performance than regency type of local governments. D_City has negative coefficient but insignificant suggesting the indifference of performance between city local government and regency local government. These results are consistent with the descriptive statistics. Performance of the province local government is lower than the performance of the city and regency local government. The coefficients of year-dummy variables are not significant at $p<0.05$ suggesting that there were no differences in performance among the three years.

\section{CONCLUSIONS}

This study provides empirical evidence of the positive association between e-government and performance of local government administration. The dimensions of e-government are also positively associated with the performance. Findings of this study also support the hypothesis that auditor opinion has a positive association with the performance of local government administration. Thus, local governments with higher e-government scores and better audit opinion tend to have higher performance.

The limitation of this study is the use of relatively few samples due to the availability of egovernment, audit opinion. and performance data. Data obtained with these criteria are only observations for 2012, 2013 and 2014. Before 2012 Performance data is available but egovernment data not available, while after 2014 e-government data is available but performance data is not yet available. Thus, the results of the study cannot be generalized to local governments that are not included in the sample.

Findings of this study suggest that e-government and audit opinion can be used as a consideration for the policymakers, for example in assessing the local government performance. All local governments should apply e-government to improve the quality of services to the community. Local governments need to continuously improve the quality of their financial statements, more specifically to improve the compliance to Indonesian government accounting standard (IGAS), the adequate disclosures of financial statements, the compliance to government regulations, and effectiveness of internal control in order to get better audit opinion from the auditors of the Audit Board (BPK). In addition, further research can be performed using more observations, when the data are available, to test the external validity of the results of this study.

\section{REFERENCES}

Andrews, Rhys; \& Boyne, George, Structural Change and Public Service Performance: The Impact of the Reorganization Process in English Local Government, Public Administration 90(2), 2012, 297-312. https://doi.org/10.1111/j.1467-9299.2011.01956.x

Bhatnagar, Subhash, The Economic and Social Impact of E-government, A Background Technical Paper for the Proposed UNDESA Publication -- E-government, the Citizen and the State: Debating Governance in the Information Age (World Public Sector Report for 2003: E-Government at the Crossroads).

Bhatnagar, Subhash C.; \& Singh, Nupur, Assessing the Impact of E-Government: A Study of Projects in India, Information Technologies \& International Development, 6(2), 2010, 109 127. 
BPK, Peraturan Badan Pemeriksa Kuangan Republik Indonesia Nomor 1 Tahun 2017. Standar Pemeriksaan Keuangan Negara [Regulation of the Audit Board of the Republic of Indonesia Number 1 Year 2017. State Auditing Standards]. Jakarta: Badan Pemeriksa Keuangan (BPK), 2017.

Buallay, Amina; Hamdan, Allam; \& Zureigat, Qasim, Corporate Governance and Firm Performance: Evidence from Saudi Arabia, Australasian Accounting, Business and Finance Journal, 11(1), 2017, 78-98. doi: 10.14453/aabfj.v11i1.6 https://doi.org/10.14453/aabfj.v11i1.6

Carpenter, Vivian L.; \& Feroz, Ehsan H., Institutional Theory and Accounting Rule Choice: An Analysis of Four US State Governments' Decisions to Adopt Generally Accepted Accounting Principles, Accounting, Organizations and Society, 26(7), 2001, 565-596. https://doi.org/10.1016/S0361-3682(00)00038-6

Chan, James L., Government Accounting: An Assessment of Theory, Purposes and Standards, Public Money \& Management, 23(1), 2003, 13-20. https://doi.org/10.1111/1467-9302.00336

Davies, Ron, E-Government: Using Technology to Improve Public Services and Democratic Participation, European Parliamentary Research Service, 2015.

Dewi, Ambar Sari, The Role of Local e-Government in Bureaucratic Reform in Terong, Bantul District, Yogyakarta Province, Indonesia, Internetworking Indonesia Journal, 3(2), 2011, 4956.

Fang, Zhiyuan, E-government in Digital Era: Concept, Practice, and Development, International Journal of the Computer, the Internet and Management, 10(2), 2002, 1-22.

Ferraz, Claudio; \& Finan, Frederico, Electoral Accountability and Corruption: Evidence from the Audits of Local Governments, The American Economic Review, 101(4), 2011, 1274-1311. doi: http://dx.doi.org/10.1257/aer.101.4.1274

Gupta, Parveen P.; Dirsmith, Mark W.; \& Fogarty, Timothy J., Coordination and Control in A Government Agency: Contingency and Institutional Theory Perspectives on GAO Audits, Administrative Science Quarterly, 39(2), 1994, 264. https://doi.org/10.2307/2393236

Hudaya, Muhammad; Smark, Ciorstan; Watts, Ted; \& Silaen, Parulian, The Use of Accountability Reports and the Accountability Forum: Evidence from an Indonesian Local Government, Australasian Accounting, Business and Finance Journal, 9(4), 2015, 57-70. doi: 10.14453/aabfj.v9i4.5 https://doi.org/10.14453/aabfj.v9i4.5

James, Oliver, Managing Citizens' Expectations of Public Service Performance: Evidence from Observation and Experimentation in Local Government, Public Administration, 89(4), 2011: 1419-1435. doi: 10.1111/j.1467-9299.2011.01962.x

Jurnali, Teddy; \& Siti-Nabiha, A. K., Performance Management System for Local Government: The Indonesian Experience, Global Business Review, 16(3), 2015, 1-13. https://doi.org/10.1177/0972150915569923

Lin, Zhiwei; Jiang, Yihong; Tang, Qingliang; \& He, Xiangjian, Does High-Quality Financial Reporting Mitigate the Negative Impact of Global Financial Crises on Firm Performance? Evidence from the United Kingdom, Australasian Accounting, Business and Finance Journal, 8(5), 2014, 19-46. doi: 10.14453/aabfj.v8i5.3 
Maclean, Sindisile, Examining Auditing as an Essential Element of Financial Management and Good Governance in Local Government, Africa's Public Service Delivery and Performance Review, 2(2), 2014, 82-101, doi: http://dx.doi.org/10.4102/ apsdpr.v2i2.53

Mir, Monir; \& Sutiyono, Wahyu, Public Sector Financial Management Reform: A Case Study of Local Government Agencies in Indonesia, Australasian Accounting, Business and Finance Journal, 7(4), 2013, 97-117. doi: 10.14453/aabfj.v7i4.7

Rana, Nripendra P.; Dwivedi, Yogesh K.; \& Williams, Michael D., Analysing Challenges, Barriers And CSF of Egov Adoption. Transforming Government: People, Process and Policy, 7(2), 2013, 177-198. doi: 10.1108/17506161311325350

Rashid, Afzalur: Zoysa, Anura De; Lodh, Sudhir; \& Rudkin, Kathy, Board Composition and Firm Performance: Evidence from Bangladesh, Australasian Accounting, Business and Finance Journal, 4(1), 2010, 76-95.

Rokhman, Ali, E-Government Adoption in Developing Countries: The Case of Indonesia, Journal of Emerging Trends in Computing and Information Sciences, 2(5), 2011, 228-236.

Rosman, Rafiqa Irahayu; Shafie, Nur Aima; Sanusi, Zuraidah Mohd; Johari, Razana Juhaida; \& Omar, Normah, The Effect of Internal Control Systems and Budgetary Participation on the Performance Effectiveness of Non-profit Organizations: Evidence from Malaysia, International Journal of Economics and Management, 10(S2), 2016, 523 - 539.

Saputra, Dany Adi, Pengaruh Hasil Pemeringkatan E-Government Indonesia (PeGI) terhadap Kinerja Penyelenggaraan Pemerintahan Daerah di Indonesia [Effect of Results of the Indonesian E-Government Ranking (PeGI) on Performance of Local Government Administration in Indonesia]. (Bachelor Thesis), Universitas Sebelas Maret, Surakarta, 2016.

Scholl, Hans J., Applying Stakeholder Theory to E-government, In Towards the E-Society, Springer US, 2002, 735-747.

Steccolini, Ileana, Is the Annual Report an Accountability Medium? An Empirical Investigation into Italian Local Governments, Financial Accountability \& Management, 20(3), 2004, 327 350. https://doi.org/10.1111/j.0267-4424.2004.00389.x

Thorsell, Anna; \& Isaksson, Anders, Director Experience and the Performance of IPOs: Evidence from Sweden, Australasian Accounting, Business and Finance Journal, 8(1), 2014, 3-24. doi: 10.14453/aabfj.v8i1.2

UNDESA, United Nations E-Government Survey 2014 - E-Government for the Future We Want, New York: United Nations Department of Economic and Social Affairs (UNDESA) - The Division of Public Administration and Development Management (DPADM), 2014.

Zeituna, Rami; \& Tian, Gary Gang, Capital Structure and Corporate Performance: Evidence from Jordan, The Australasian Accounting Business \& Finance Journal, 1(4), 2007, 40-61. 


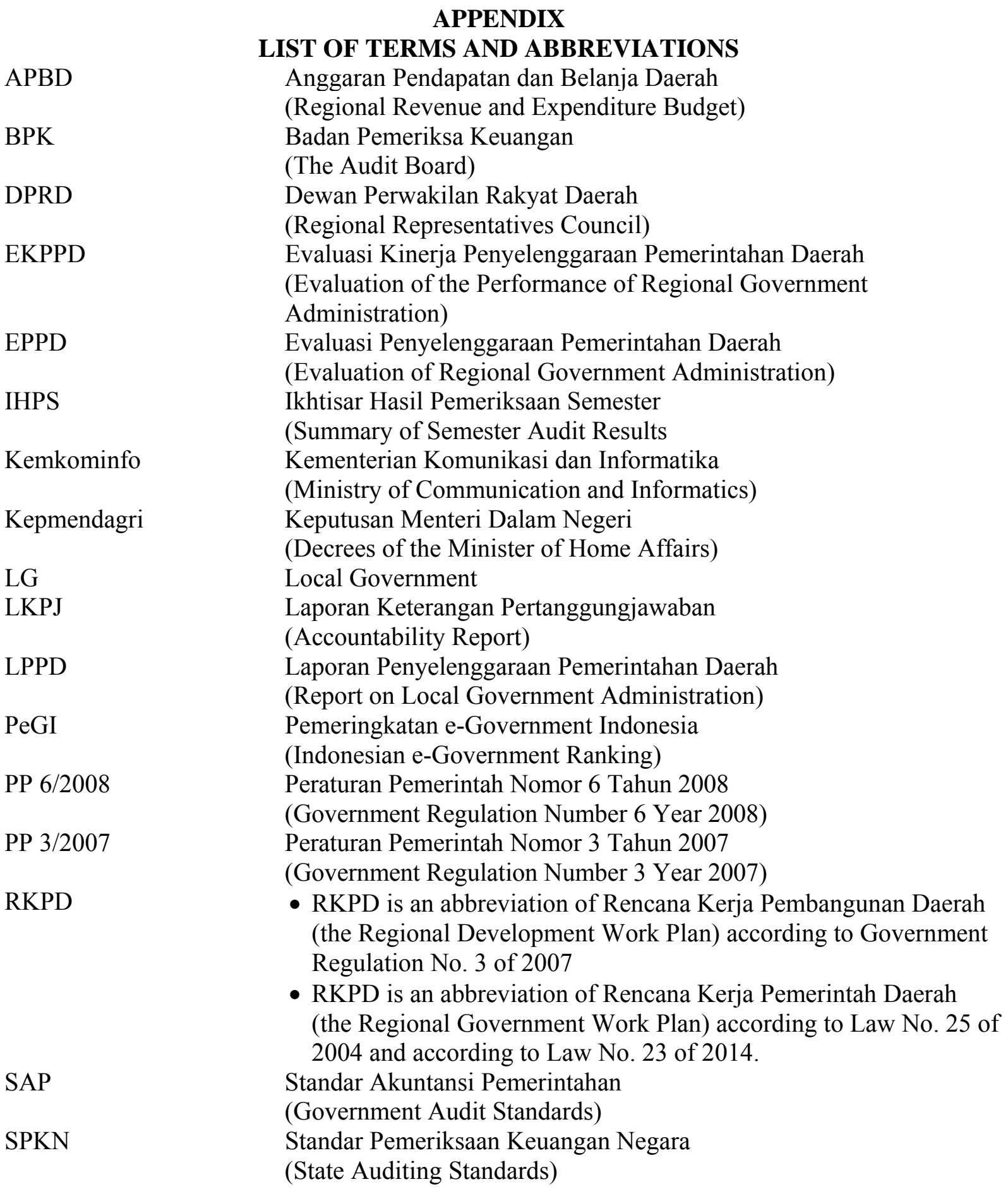

